\title{
Secondary physical education, participation by sex in moderate to vigorous physical activity Educación física en secundaria, participación por sexo en actividad física moderada a vigorosa Javier Arturo Hall-López \\ Autonomous University of Baja California (México)
}

\begin{abstract}
Objective: To compare by sex the participation in moderate to vigorous physical activity in secondary school physical education classes. Method: The research design was comparative descriptive, with convenience sampling, 188 adolescents with an average age of $12.5 \pm 0.7$ enrolled in public secondary schools in the city of Mexicali, Baja California participated. Mexico. The system for observing fitness and instruction time (SOFIT) was used to determine the moderate to vigorous physical activity of 47 physical education classes. Results: The equality of the variance was calculated by the Student $t$ test for independent samples less than ád» 0.05 ; finding significant differences of participation in vigorous moderate physical activity lower in women than in men during physical education class $(\mathrm{P}-\mathrm{Value}=.002)$ with a difference percentage of $32.5(\Delta \%)$ between men and women. Conclusion: In a constructive way, it is recommended to take pedagogical actions with cooperative and simultaneous participation of students in moderate to vigorous physical activity for at least $50 \%$ of class time, and guide educational content to involve students in the movement both genders, as established by UNESCO to provide quality physical education.
\end{abstract}

Keywords: Physical Education, Secondary Education, Sex, Physical Activity.

Resumen. Objetivo: Comparar por sexo la participación en actividad física moderada a vigorosa en clases de educación física de secundaria. Método: El diseño de la investigación fue descriptivo comparativo, con muestreo por conveniencia, participaron 188

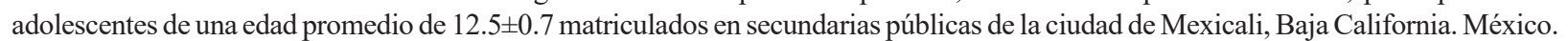
Se utilizó como instrumento de evaluación el Sistema para observar el tiempo de instrucción de actividad física (SOFIT), para determinar la actividad física moderada a vigorosa de 47 clases de educación física. Resultados: La igualdad de la varianza se calculó mediante la prueba t-Student para muestras independientes resultando por sexo menor a ád» 0.05 ; encontrando diferencias significativas de participación en actividad física moderada vigorosa menores en mujeres que en hombre durante la clase de educación física (P-Valor $=.002)$ con un porcentaje de diferencia de $32.5(\Delta \%)$ entre hombres y mujeres. Conclusión: De manera constructiva, se recomienda tomar acciones pedagógicas con participación cooperativa y simultanea de los estudiantes en actividad física moderada a vigorosa por lo menos el 50\% del tiempo de la clase, y guiar contenidos educativos para involucrar en el movimiento a los estudiantes de ambos géneros, como lo establece la UNESCO para brindar una educación física de calidad.

Palabras clave: Educación Física, Educación Secundaria, Sexo, Actividad Física.

\section{Introduction}

The United Nations Educational Scientific and Cultural Organization (UNESCO) establishes in its guide aimed at policy makers working on physical education, that school is a key element in providing girls with the information, skills and confidence necessary to practice physical activity and sport throughout their lives (McLennan, \& Thompson, 2015), likewise, within the sustainable development objectives proposed by the United Nations (UN) to reduce extreme poverty in various dimensions, gender equality is found encompassing the educational field (Pérez Betancourt, \& Betancourt Rodríguez, 2019), which have established applicability in physical education (Frizzo, and Silva Souza, 2019).

Meta-analysis and systematic reviews identify that sedentary adolescents are at greater risk of presenting pathologies associated with obesity (Brooke et al., 2014; Sims, Scarborough, \& Foster, 2015). Within the Mexican context, in terms of physical culture, imbalances between men and women (Flores Fernandez, 2019) and with regards to physical activity have been identified. The results of the Halfway National Health and Nutrition Survey ENSANUT MC (by its Spanish acronym) 2016, found that female adolescents

Fecha recepción: 26-12-19. Fecha de aceptación: 13-03-20

Javier Arturo Hall-López

javierhall@uabc.edu.mx engage in less physical activity $(12.7 \%)$ compared to male adolescents (17.2\%).

There are different tools to assess physical activity within the school environment, using valid and reliable questionnaires, observational instruments, or equipment (McKenzie and van der Mars, 2015). Among which is the System for Observing Fitness Instruction Time SOFIT (Mckenzie, 2002; Mckenzie et al., 1992). In Mexico, research that evaluates physical activity using this system has been performed during a school day in primary education, displaying in the quantity of moderate to vigorous physical activity: a greater participation in boys than in girls (HallLópez et al., 2017, Hall-López et al., et al., 2019).

While reviewing the state of affairs, various individual and social multifactorial factors linked to physical-sports practice from the gender perspective were identified (Torre Ramos, 2002, Vicente-Pedraz, \& Paz Brozas-Polo, 2017). Research performed in the school environment identifies less physical activity in adolescent women (Beltrán Carrillo et al., 2019) as well as a lower intention by women to actively participate in physical education class (Zueck Enríquez et al., 2019). It has been identified that the role of teachers in promoting effort in physical education class may be insufficient to promote moderate to vigorous physical activity (Retamal-Valderrama, Delgado Floody, Espinoza-Silva, \& Jerez Mayorga, 2019).

Internationally, participation standards in moderate and vigorous physical activity have been recommended by the 
United States' National Association for Sport and Physical Education (NASPE), establishing that in physical education classes, teachers must design actions for students to participate in activities that have at least a moderate to vigorous intensity above $50 \%$ of the class time, that is, being active with an energy expenditure similar to walking or running (Banville, 2006). Thus, promoting an improvement in cardiorespiratory fitness levels (Guijarro-Romero, MayorgaVega, Casado-Robles, \& Viciana, 2019); and in this way, contributing to the recommendations of the World Health Organization (WHO) which establishes a minimum dedication of 60 minutes a day in physical activity with moderate to vigorous intensity in children and adolescents between ages of 5 to 17 (WHO, 2014).

According to our knowledge, identifying specific studies that evaluate the participation in moderate to vigorous physical activity in physical education according to gender in secondary school has been complicated; therefore, the present study aims to perform a comparative analysis by sex of moderate to vigorous physical activity in secondary school students.

\section{Method}

\section{Participants}

The present research was approved in the Coordination of Graduate Studies and Research of the Autonomous University of Baja California protocol 149/2/C/5/21, performed between August and December 2019, under a comparative cross-sectional methodological design with a non-probability convenience sample (Thomas, Nelson, \& Silverman, 2015), with the consent of the directors and teachers of public educational institutions, programming evaluation schedules and following the ethical principles of research involving human subjects of the Declaration of Helsinki (Puri, Suresh, Gogtay, \& Thatte, 2009).

\section{Instruments}

The moderate to vigorous physical activity of 47 first grade physical education classes of secondary school in students with an average age of $12.5 \pm 0.7$ years was evaluated using the System for Observing Fitness and Instruction Time (SOFIT), (McKenzie, Sallis y Nader, 1992).

\section{Procedures}

The system for system for observing fitness and instruction time (SOFIT), as means of methodology, was utilized by randomly choosing 4 students from each physical education class ( 2 males and 2 females) according to the official class list, who were observed in a rotating sequence of 12 intervals for 20 seconds each, repeating the observations throughout the entirety of the class, following an audio that indicated the recording times of the activity. To determine participation in physical activity, codes were used to classify activity levels, which allowed to estimate the energy expenditure associated with physical activity. This procedure was classified into five codes: 1) lying down, 2) sitting, 3) standing, 4) walking, and 5) very active which corresponds to running or an activity with a higher energy expenditure. From the quantification of these codes, the moderate to vigorous physical activity index (IAFMV by its Spanish acronym) of one hundred and eighty-eight students was obtained, adding percentage codes 4) walking and 5) very active of the total time of the physical education class.

\section{Statistical analysis}

A statistical analysis with the Statistical Package for the Social Sciences (SPSS) version 23.0 for Windows was performed (IBM Corporation, New York, USA); calculating the descriptive values of the variables; and the percentage difference ( $\ddot{\mathrm{A}} \%$ ) ([(Mean-2 - Mean-1)/Mean-1]x 100)(Vincent, 2012). According to the used methodology, an alternate and null hypothesis test was established to verify the normality of the groups and homogeneity of the variance of the data, the Kolmogorov-Smirnov statistical test was utilized with a significance level of P- Value eH 0.05; as a cross-sectional study when comparing as fixed variables of two groups 1) men or 2) women and moderate to vigorous physical activity in physical education class in men and women, having as a random variable the moderate to vigorous physical activity index. The Student's t-test for independent samples calculating the equality of the variance was utilized, establishing a level of ádH 0.05 .

\section{Results}

The research evaluated 47 physical education classes in secondary school, with an average duration in minutes of $42.07 \pm 5.2$ (range from 26 to 51 minutes). The mean descriptive statistics $(M)$ and the standard deviation $( \pm \mathrm{SD})$ of the five codes: 1) lying down, 2) sitting, 3) standing, 4) walking, and 5 ) very active evaluated by the system for observing fitness and instruction time can be found in Table 1, as well as the results related to normality of the groups and homogeneity of the variance of the data.

\begin{tabular}{|c|c|c|c|c|}
\hline \multirow{3}{*}{ Variables } & \multirow{2}{*}{\multicolumn{4}{|c|}{ Physical Education Classes in Secondary School }} \\
\hline & \multicolumn{2}{|r|}{ Men } & & \\
\hline & $\mathrm{M} \pm \mathrm{SD}$ & $\begin{array}{l}\text { Kolmogorov-Smirnov } \\
\text { Test }\end{array}$ & $\mathrm{M} \pm \mathrm{SD}$ & $\begin{array}{c}\text { Kolmogorov-Smirnov } \\
\text { Test }\end{array}$ \\
\hline 1) lying down(\%) & $3.7 \pm 0.7$ & 0.357 & $4.9 \pm 0.7$ & 0.152 \\
\hline 2) sitting (\%) & $15.1=$ & 6 & 23 & 0.219 \\
\hline 3) standing (\%) & $38.3 \pm 11.2$ & 0.672 & $49.2 \pm 10.1$ & 0.512 \\
\hline 4) walking (\%) & $19.6 \pm 6.1$ & & $13.3 \pm 4.3$ & 0.186 \\
\hline 5) very active (\%) & $13.3 \pm 3.8$ & 0.589 & $8.9 \pm 10.2$ & 0.617 \\
\hline \multicolumn{5}{|c|}{$\begin{array}{l}\text { Note: Gender comparative table of the mean, standard deviation }( \pm) \text { normality and homogeneity } \\
\text { of the variance between groups using the Kolmogorov-Smirnov statistical test, } * p=0.05 \\
\text { Variables: Percentage distribution of the intensity of physical education classes evaluated by } \\
\text { SOFIT; Classifying the codes as 1) lying down, 2) sitting, 3) standing, 4) walking, and 5) very } \\
\text { active that corresponds to running or an activity with a higher energy expenditure. Evaluated } \\
\text { with the system for observing fitness and instruction time SOFIT; (Mckenzie et al., 1992). }\end{array}$} \\
\hline
\end{tabular}

The calculation of the equality of variance of the moderate to vigorous physical activity index (IAFMV) of the classes of physical education in secondary school according to sex can be observed in figure 1. The student's t-test reported significant differences in moderate to vigorous physical activity in physical education, with higher averages in male adolescents compared to female adolescents (0.002), and a percentage difference of $32.5(\ddot{\mathrm{A}} \%)$ between men and women. 


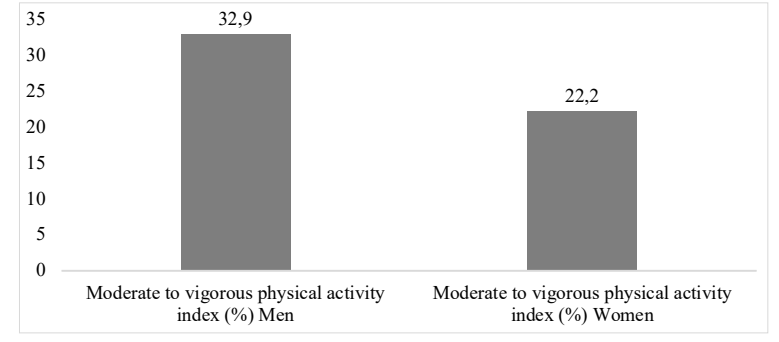

Note: Average percentage of moderate to vigorous physical activity index IAFMV $=$ the percentage sum of the codes 4) walking and 5) very active that corresponds to running or an active with a higher energy expenditure or the total time or physical education classes in

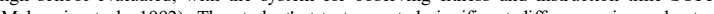
(Mckenzie et al., 192). The stidents t test reponed significant differences in moderate ents $(0.002)$

Figure 1. Moderate to vigorous physical activity index (IAFMV) in \% of men and women in physical education class in secondary school.

\section{Discusion}

The main result of this research was that male students present a significantly higher participation in moderate to vigorous physical activity than women during physical

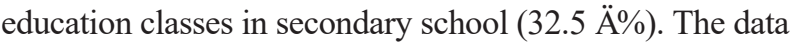
is consistent with studies performed in the Mexican primary school educational context. Using the same methodological procedure, significant differences are reported in moderate to vigorous physical activity in physical education with $25.7 \%$ participation in girls and $32.1 \%$ in boys (Pérez-Bonilla, 2009). Another study also found less moderate to vigorous physical activity in girls (36.8\%) compared to boys (42.2\%) (Jennings-Aburto et al., 2009). The average moderate to vigorous physical activity index of physical education classes taught by teachers evaluated in secondary school was of $27.5 \%$, which when compared with the standards established internationally by the United States' National Association for Sport and Physical Education (NASPE) physical education classes did not achieve moderate to vigorous intensity for at least $50 \%$ of class time (Banville, 2006), these values are consistent with research conducted in primary and secondary education in similar geographical contexts (Hall-López et al., 2017, Hall-López et al., 2018).

In Mexico, the physical education program establishes in the graduation profiles collaboration and teamwork as well as attention to the body and health (SEP, 2017), reason for which these elements could be taken into account to intentionally lead physical education classes to generate opportunities to participate in motor skill activities regardless of gender. Teaching strategies have been recommended to minimize inequality in this subject (López Pastor, 2012); hence, the importance of teachers in directing the content of educational programs, avoiding gender-related stereotypes and giving importance to equal participation of students in physical education class (Alvariñas-Villaverde, \& Pazos González, 2018).

Physical education classes with a low effort promotion as well as intensity of physical activity with less than $50 \%$ of the class time have been evaluated by teachers (RetamalValderrama, et al., 2019), and when analyzing it with our findings; moderate to vigorous physical activity involving students is of $32 \%$. Other research establishes as a factor of intensity in physical education class the task-focused motivational climate in which students remain more in moderate to vigorous physical activity as opposed to teachers who focus on performance-oriented climate (Wadsworth, Robinson, Rudisill and Gell, 2013), these results are important when adjusting teaching and implementing strategies, content, and the use of materials to guarantee quality in the movement in physical education (Jovanoviæ and Miniæ, 2018). In the above, Kwon, Welch, and Mason (2020), establish the importance of teachers to associate motor skill content in promoting physical activity in physical education class regardless of the students' sex.

\section{Conclusions}

As a conclusion, a lower participation in vigorous moderate physical activity in women compared to men can be identified in physical education classes of secondary school. Speaking constructively, it is recommended to take pedagogical actions with cooperative and simultaneous participation of students in moderate to vigorous physical activity by at least $50 \%$ of the class time regardless of gender, and in this way contributing in the school environment with the recommendations for children and adolescents established by the World Health Organization (WHO) for the achievement of at least 60 minutes a day in moderate to vigorous physical activity, as well as, in the physical education class, guiding educational content to involve students of both genders in the movement, as established by UNESCO to provide quality physical education.

\section{Financing}

Research was funded by the 21 convocatoria interna de proyectos de investigación of the Autonomous University of Baja California, Mexico protocol 149/2/C/5/21.

\section{References}

Alvariñas-Villaverde, M., \& Pazos-González, M. (2018). Estereotipos de género en Educación Física, una revisión centrada en el alumnado. Revista electrónica de investigación educativa, 20(4), 154-163. https://dx.doi.org/10.24320/redie.2018.20.4.1840

Banville, D. (2006). Analysis of exchanges between novice and cooperating teachers during internships using the NCATE/NASPE standards for teacher preparation in physical education as guidelines. Research Quarterly for Exercise and Sport, 77(2), 208-221. doi: 10.1080/02701367.2006.10599355

Beltrán Carrillo, V., Sierra, A., Jiménez Loaisa, A., González-Cutre, D., Martínez Galindo, C., \& Cervelló, E. (2016). Diferencias según género en el tiempo empleado por adolescentes en actividad sedentaria y actividad física en diferentes segmentos horarios del día (Gender differences in time spent by adolescents in sedentary and physical activity in different day segmen. Retos, 0(31), 3-7. https://recyt.fecyt.es/index.php/retos/article/view/36207

Brooke, H. L., Corder, K., Atkin, A. J., y van Sluijs, E. M. (2014). A systematic literature review with meta-analyses of within-and between-day differences in objectively measured physical activity in school-aged children. Sports Medicine, 44(10),27-38. doi: 10.1007/s40279-014-0215-5.

Flores Fernandez, Z. (2019). Mujer y deporte en México. Hacia una igualdad sustancial. Women and sport in México. Towards a substantive equality. Retos, 37(37), 222-226. https:// recyt.fecyt.es/index.php/retos/article/view/71684

Frizzo, G., and Silva Souza M. (2019). Educação física nas diretrizes da unesco: o paradigma da aptidão física e da saúde na formação 
do capital humano. Movimento, Porto Alegre, 25: e25022, 112. DOI: https://doi.org/10.22456/1982-8918.76037

Guijarro-Romero, S., Mayorga-Vega, D., Casado-Robles, C., \& Viciana, J. (2019). Una unidad didáctica intermitente de acondicionamiento físico solo mejora los niveles de capacidad cardiorrespiratoria de los estudiantes con un perfil no saludable de condición física (An intermittent physical fitness teaching unit only improves cardior. Retos, 38(38), 8-15. https:// recyt.fecyt.es/index.php/retos/article/view/73605

Jennings-Aburto, N., Nava, F., Bonvecchio, A., Safdie, M., Gonzalez-Casanova, I., Gust, T., \& Rivera, J. (2009). Physical activity during the school day in public primary schools in Mexico City. Salud Publica Mexico, 51(2), 141-147. doi:10.1590/s0036-36342009000200010

Jovanoviæ, M., \& Miniæ, V. (2018). Teachers of physical education on improving the quality of teaching with continuous adjustments to the curricula. Facta Universitatis, Series: Physical Education and Sport, 16,(3). 651-661. https://doi.org/10.22190/FUPES180208059J

Hall-López, J. A., Ochoa-Martínez, P. Y., Meza, F., Sánchez, R., y Sáenz-López, P. (2019). Comparación de la actividad física por género y grasa corporal en escolares mexicanos. Revista Iberoamericana de Ciencias de la Actividad Física y el Deporte, 8(1),1-14. http://dx.doi.org/10.24310/riccafd.2019.v8i1.5763.

Hall-López, J. A., Ochoa-Martínez, P. Y., Meza Correa, F., López Campos, C. E., y Sáenz-López Buñuel, P. (2017). Actividad física y percepción de esfuerzo por género en educación física y recreo de escolares mexicanos. Educación Física y Deporte, 36(2), 1-9. http://aprendeenlinea.udea.edu.co/revistas/ index.php/educacionfisicaydeporte/issue/view/3390/showToc

Hall-López, J. A., Ochoa-Martínez, P. Y., Zuñiga, R., Monreal, L. R., y Sáenz-López, P. (2017). Moderate-to-vigorous physical activity during recess and physical education among mexican elementary school students. Retos, 31, 137-139. https:// recyt.fecyt.es//index.php/retos/article/view/49640

Hall-López, J. A., Ochoa-Martínez, P. J., Macías, R. A., Zuñiga, R., y Sáenz-López, P. (2018). Actividad física moderada a vigorosa en educación física y recreo en estudiantes de primaria y secundaria de la frontera México-USA. Sportis: Revista Técnico-Científica del Deporte Escolar, Educación Física y Psicomotricidad, 4(3), 426-442.http://revistas.udc.es/ index.php/SPORTIS/article/view/sportis.2018.4.3.3175

Kwon, S., Welch, S. \& Mason, M. (2020). Physical education environment and student physical activity levels in low-income communities. BMC Public Health, 20, 147: 1-9 https://doi.org/ 10.1186/s12889-020-8278-8

McLennan, N. \& Thompson, J. LIBRO: EDUCACIÓN FÍSICA DE CALIDAD (EFC): GUÍA PARA LOS RESPONSABLES POLÍTICOS. Organización de las Naciones Unidas para la Educación, la Ciencia y la Cultura UNESCO. 2015. I.S.B.N. 978-92-3-300012-4. PUBLICADO: https:// unesdoc.unesco.org/ark:/48223/pf0000231340

McKenzie, T., L. SOFIT. System for Observing Fitness Instruction Time. Overview and Training Manual. San Diego, CA: San Diego State University. 2002. https://thomckenzie.com/usefultools/observation/

Mckenzie, T. L., Sallis, J. F., y Nader, P. R. (1992). Sofit-System for Observing Fitness Instruction Time. Journal of Teaching in Physical Education, 11(2),195-205. doi: https://doi.org/ 10.1123/jtpe.11.2.195

McKenzie, T. L., y van der Mars, H. (2015). Top 10 research questions related to assessing physical activity and its contexts using systematic observation. Research Quarterly for Exercise and Sport, 86(1):13-29. doi:10.1080/02701367.2015.991264

Pastor Gosálbez, I., Acosta Sarmiento, A., Torres Coronas, T., y Calvo Merino, M. (2019). Los planes de igualdad en las universidades españolas. Situación actual y retos de futuro. Educación XX1, 23(3), 1-28. https://doi.org/10.5944/ educxx1.23873
Pérez Betancourt, A., y Betancourt Rodríguez, M. Z. (2019). El enfoque de género desde la formación docente y su relación con la ciencia, la tecnología y la sociedad. Revista Boletín Redipe, 8(3), 200-208. https://revista.redipe.org/index.php/1/ article/view/713

Pérez-Bonilla, A. M. (2009). Impacto de la clase de educación física sobre la actividad moderada y vigorosa en niños de primaria. Revista Méxicana de Investigación en Cultura Física y Deporte, 1(1),150-172.http://revista.ened.edu.mx/index.php/ revistaconade/issue/view/1

Puri, K. S., Suresh, K. R., Gogtay, N. J., y Thatte, U. M. (2009). Declaration of Helsinki implications for stakeholders in research. Journal of Postgraduate Medicine,55(2),131-134. doi: 10.4103/0022-3859.52846

Retamal-Valderrama, C., Delgado Floody, P., Espinoza-Silva, M., \& Jerez-Mayorga, D. (2019). Comportamiento del Profesor, Intensidad y Tiempo Efectivo de las Clases de Educación Física en una escuela pública: Un acercamiento a la realidad (Teacher's Behavior, Intensity and Effective Time of Physical Education Classes in a Public School: An Appro. Retos, 0(35), 160-163. https://recyt.fecyt.es/index.php/retos/article/view/63847

Sims, J., Scarborough, P., y Foster, C. (2015). The Effectiveness of Interventions on Sustained Childhood Physical Activity: A Systematic Review and Meta-Analysis of Controlled Studies. PLoS One, 10(7), e0132935. doi:10.1371/journal.pone.0132935

Secretaria de Educación Pública (SEP) Aprendizajes Clave para la Educación Integral. Educación Física. Educación Básica. Plan y Programas de Estudio y sugerencias de evaluación. Primera edición 2017, Ciudad de México. ISBN: 978-607-97644-4-9. Disponible también en la website: https:// www.aprendizajesclave.sep.gob.mx/

Thomas, J. R., Nelson, J. K., y Silverman, S. J. Research Methods in Physical Activity (7th. Ed.). Human Kinetics. 2015. Champaign, Ilinois: Human Kinetics. ISBN: 9781450470445. PUBLICADO: http://www.humankinetics.com/products/allproducts/research-methods-in-physical-activity-7th-edition

Torre Ramos, E. (2002). Factores personales y sociales vinculados a la práctica físico-deportiva desde la perspectiva del género. Apunts. Educación física y deportes, 4(70), 83-89. https://www.raco.cat/index.php/ApuntsEFD/article/view/ 305889

Vicente-Pedraz, M., y Paz Brozas-Polo, M. (2017). Sexo y género en la contienda identitaria del deporte. Propuesta de un debate sobre la competición deportiva multigénero. (Sex and gender in the contest of identity in sport. A proposal for a debate on multi-gender sports competition). CCD. Cultura Ciencia Deporte, 12(35), 101-110. doi:http://dx.doi.org/10.12800/ ccd.v12i35.881

Vincent W. J. Statistics in kinesiology (4nd Ed.). Champaign, Ilinois: Human Kinetics; 2012.ISBN-13: 978-1450402545, ISBN-

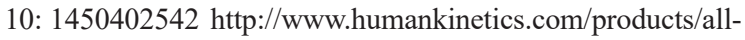
products/statistics-in-kinesiology-4th-edition

World health Organization WHO data revisited. (n.d.). Retrieved january 9, 2019, from the Global Strategy on Diet, Physical Activity and Health, Physical Activity and Young People, Recommended levels of physical activity for children aged 517 years; website, http://www.who.int/dietphysicalactivity/ factsheet_young_people/en/

Wadsworth, D. D., Robinson, L. E., Rudisill, M. E., \& Gell, N. (2013). The effect of physical education climates on elementary students' physical activity behaviors. The Journal of school health, 83(5), 306-313. https://doi.org/10.1111/josh.12032

Zueck Enríquez, M., Ramírez García, A., Rodríguez Villalobos, J., y Irigoyen Gutiérrez, H. (2019). Satisfacción en las clases de Educación Física y la intencionalidad de ser activo en niños del nivel de primaria (Satisfaction in the Physical Education classroom and intention to be physically active in Primary school children). Retos, 37(37), 33-40. https://recyt.fecyt.es/ index.php/retos/article/view/69027 